
\title{
The MICROCOMPUTER
USERS HANDBOOK 1985
}




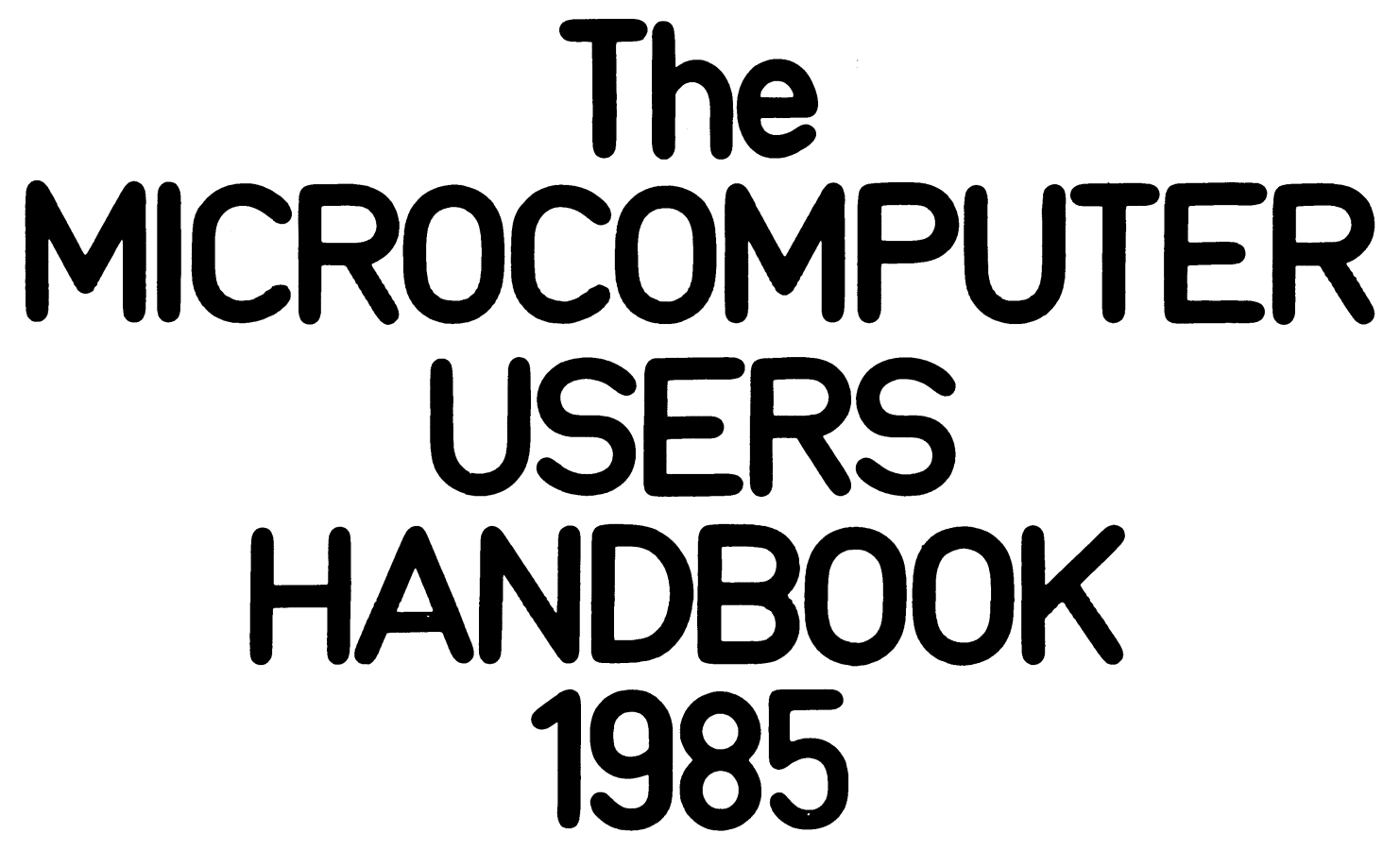

The complete and up to date guide to buying a business computer

\section{Dennis Longley and Michael Shain}

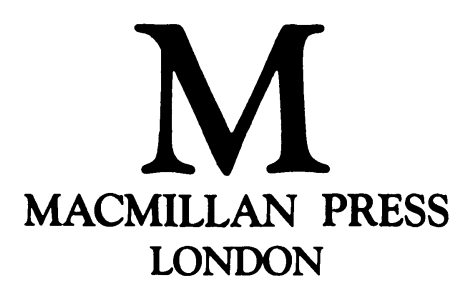


(C) The Macmillan Press Ltd, 1985

All rights reserved. No reproduction, copy or transmission of this publication may be made without written permission.

No paragraph of this publication may be reproduced, copied or transmitted save with written permission or in accordance with the provisions of the Copyright Act 1956 (as amended).

Any person who does any unauthorised act in relation to this publication may be liable to criminal prosecution and civil claims for damages.

First published 1985 by

THE MACMILLAN PRESS LTD

London and Basingstoke

Associated companies in Auckland, Delhi, Dublin, Gaborone, Hamburg, Harare, Hong Kong, Johannesburg, Kuala Lumpur, Lagos, Manzini, Melbourne, Mexico City, Nairobi, New York, Singapore, Tokyo.

\section{British Library Cataloguing in Publication Data}

Longley, Dennis

The microcomputer users handbook 1985.

1. Computer networks 2. Microcomputers

I. Title II. Shain, Michael

001.64'04 TK105.5

ISBN 978-0-333-36866-4

ISBN 978-1-349-07237-8 (eBook)
The paperback edition of this book is sold subject to the condition that it shall not, by way of trade or otherwise, be lent, resold, hired out, or otherwise circulated without the publisher's prior consent in any form of binding or cover other than that in which it is published and without a similar condition including this condition being imposed on the subsequent purchaser

\section{IMPORTANT NOTE}

Whilst every care has been taken in compiling the information contained in this Handbook, the Publishers and Editors accept no responsibility for any errors or omissions.

\section{CORRESPONDENCE}

Letters on editorial matters should be addressed to:

Dennis Longley and Michael Shain

The Microcomputer Users Handbook

4 Little Essex Street

London WC2R 3LF

Enquiries about despatch, invoicing or commercial matters should be addressed to:

Customer Services Department

The Macmillan Press Ltd

Houndmills, Basingstoke

Hampshire RG21 2XS

For information about placing advertising in this publication contact:

Magazine Co-Partnership

100 Fleet Street

London EC4B 4AA

(01) 3534612 


\section{CONTENTS}

The following contents listing has been expanded to include all sections and sub-sections as well as the chapters. This has been done to help the reader to find easily all relevant areas of interest in the Handbook.

\section{INTRODUCTION}

HOW TO USE THIS HANDBOOK

ABOUT THE CHAPTERS

ACKNOWLEDGEMENTS

1

1.1

1.1 .1

1.1.2

1.1.3

1.1.4

1.1 .5

1.1.6

1.1.7

1.1.8

1.1.9

1.1.10

1.1.11

1.1.12

1.1.13

1.1.14

1.1.15

1.1.15.1

1.1.15.2

1.1.15.3

1.1.15.4

1.1.15.5

1.1.16

1.1.17

1.1.18

1.2

1.2.1

1.2 .2

1.2.3

1.2.4

1.2.4.1

1.2.4.2

1.2.4.3

1.2.4.4

1.2.4.5

1.2.5

1.2.5.1

1.2.5.2

1.2.5.3

1.2.5.4

1.2.5.5

1.2.5.6

1.2.6

\section{HOW TO BUY A MICROCOMPUTER}

ROLE OF THE MICROCOMPUTER IN 1 BUSINESS

Introduction: What You Need To 1 Know

The Importance of Microcomputers 1 for Business Users

Types and Uses of Microcomputers 2

Accounting Systems

Financial Planning

Information Retrieval

Sales Aids

Inventory Management

Production Management

Single Task and Calculation Systems

Keyless and Other Special Systems 4

Portable Systems

Microcomputer Facilities

Application Software

System Building and Utility Software 6

Financial modelling

Data management systems

Graphics

Word processing

Electronic mail and other data

communication systems

Standard Application Packages 7

Tailored Software and User

Programming

Conclusions

\section{THE RIGHT WAY TO BUY A}

COMPUTER SYSTEM

What You Need To Know

The Computer as an Investment

Objectives and Requirements

Software

Operating system

Programming language

System building and utility packages 10

Application packages

Tailored and user software

Hardware

Processor

Input

Internal storage

Backing storage

Printing

Other devices

Balancing Hardware and Software
1.2 .7

1.2.8

1.2 .9

1.2.9.1

1.2.9.2

1.2.9.3

1.2.9.4

1.2.9.5

1.2.9.6

1.2.9.7

1.2.9.8

1.2.9.9

1.2.9.10

1.2.9.11

1.2.10

1.3

1.3.1

1.3.2

1.3.3

1.3.3.1

1.3.3.2

1.3.4

1.3.4.1

1.3.4.2

1.3.4.3

1.3.5

1.3.6

1.3.6.1

1.3.6.2

1.3.6.3

1.3.6.4

1.3.6.5

1.3.6.6

1.3.6.7

1.3.6.8

1.3.6.9

1.3.7

1.3.8

1.3.9

1.4

1.4 .1

1.4 .2

1.4 .3

1.4 .4

1.4 .5

1.4 .6

1.4 .7

1.4 .8

1.4 .9

1.4.10

1.4.11

1.4.12

1.5

1.5.1

1.5.2
The Shopping List

12

Suppliers and the Microcomputer

Market

Contract Arrangements

Scope of contracts

The equipment schedule

Environment

Delivery

Period of warranty

Misuse

Fitness for purpose

Software documentation

Checklist of contract points

Confidence

What to do if a contract is not

satisfactory

Conclusions

MAINTENANCE AND AFTER SALES

17 SUPPORT

What You Need To Know 17

The Need for Support 17

Maintenance of Equipment 18

Contract arrangements $\quad 18$

Hardware faults 18

Maintenance of Software $\quad 18$

Software support 18

Software contracts $\quad 19$

Software faults 19

Dealing with Failures $\quad 19$

Self-Help and Self-Protection 20

Built in protection 20

Data errors 20

Operating error $\quad 20$

'Friendly' systems 20

Programmed controls 21

'Help' routines 21

Recovery from system failure $\quad 21$

Care in use 22

Stand-by arrangements 23

Maintenance Questions to be Asked 23

in a System Appraisal

After Sales Support 23

Conclusions 23

PLANNING FOR GROWTH 24

What You Need To Know 24

The Need to Expand 24

The Capacity of a Computer System 24

Single-User Systems 25

Introducing a Second Computer 26

Multi-User Systems 26

Workstations and Intelligent Terminals26

Local Area Networks 27

Software Compatibility 27

Choosing Systems for Growth 27

The Future for Business 29

Microsystems

Conclusions

30

PROJECT PLANNING AND STAFF 30

PARTICIPATION

What You Need To Know 30

Understanding Computer Systems $\quad 30$ 


\subsection{3}

1.5 .4

1.5 .5

1.5.6

1.5.7

1.5.8

1.5.9

1.5.10

1.5.11

1.5.12

\section{6}

1.6 .1

1.6 .2

1.6 .3

1.6.4

1.6 .5

1.6.6

1.6.7

1.6 .8

1.6 .9

1.6.10

1.6.11

\section{2}

2.1

2.1.1

2.1.2

2.1.3

2.1.4

2.1 .5

2.1.6

2.1.7

2.1.8

2.2

2.2.1

2.2.2

2.2.3

2.2.3.1

2.2.3.2

2.2.3.3

2.2.4

2.3

2.3.1

2.3.2

2.3.2.1

2.3.2.2

2.3.3

2.3.3.1

2.3.3.2

2.3.3.3

2.3.3.4

2.3.4

2.4

2.4 .1
Influences on Effectiveness of Systems

Attitudes to System Change

Information about the Project

Specifications of Hardware and

Software Requirements

Demonstrating and Testing Systems

Training

Operating Instructions

Implementation

Evaluation

Conclusions

\section{QUESTIONS TO BE ASKED AT}

DEMONSTRATIONS

What You Need To Know

Exhibitions

Selling Demonstrations

Visits To Existing Users

Acceptance Tests

Asking the Right Questions

Unsatisfactory Features of

Demonstrations

Selling Senior Management

Questions about Software

Questions about Hardware

Conclusions

\section{UNDERSTANDING}

MICROCOMPUTERS

HOW MICROCOMPUTERS WORK
Introduction
The Microcomputer System
The Clerk Model
The Program
Black Box Model
Input/Output
Can it Make a Mistake?
Conclusions

41

41

41

41

42

43

43

45

45

\section{FILES AND RECORDS}

What You Need To Know

45

Files and Records: An Overview 45

Files and Records: A Detailed Account47

Introduction

File processing

Housekeeping

Relationship to Other Sections

MICROCOMPUTER HARDWARE

What You Need To Know

Microcomputer Hardware: An

Overview

Introduction

Microcomputer building blocks

Microcomputer Hardware:

Account

Introduction

CPU

Memory

Buses and interfaces

Relation to Other Sections

MICROCOMPUTER PERIPHERALS

What You Need To Know
Conventional Peripherals

Introduction

Keyboards

Video monitors and terminals

Backing storage

Printers

Special Applications

Communications

Input devices

Output devices

Conclusions

MICROCOMPUTER SOFTWARE

What You Need To Know

Microcomputer Software: An

Overview

Relation to Other Sections

OPERATING SYSTEMS

Operating Systems: An Overview 72

The operations 72

Operating systems and Application 73 Programs

MS-DOS:A Microcomputer Operating 73

System

Introduction

What is MS-DOS?

Getting started

Housekeeping

Copying and editing

User defined routines

Programs

Conclusion

HIGH LEVEL LANGUAGES 77

What You Need To Know 77

High Level Languages: An Overview 78

Introduction 78

Translation 78

Typical languages 78

High Level Languages: Detailed 79

Account

Introduction

Selecting the language

Programming in BASIC

An example of a BASIC program

Learning BASIC

Relation to Other Sections

LOW LEVEL LANGUAGES

What You Need To Know

Low Level Languages: an Overview 83

Architecture

Instruction formats

Example of commonly used

instructions

Assembling

Testing

Relation to Other Sections

COMPILERS, INTERPRETERS AND 87

ASSEMBLERS 


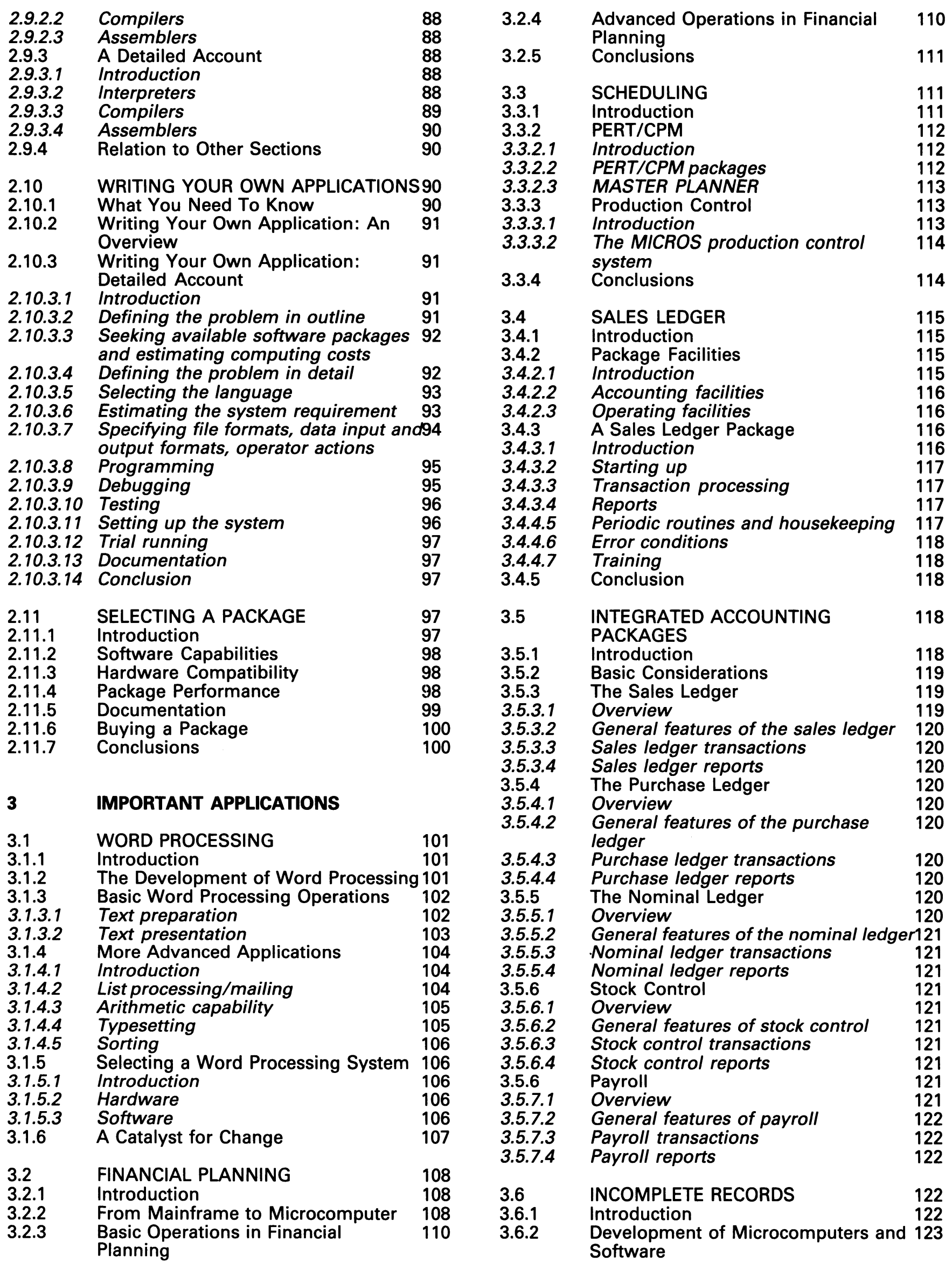


3.6.3 General Operations 123

3.6.4 Conclusions 125

3.7 DATABASE PACKAGES 125

3.7.1 What You Need To Know 125

3.7.2 Conventional Files and Databases 126

3.7.2.1 Introduction 126

3.7.2.2 The conventional approach to file 126 processing

3.7.2.3 Problems inherent in conventional file127 processing

3.7.2.4 The database solution 127

3.7.3 Database Facilities 128

3.7.3.1 Review of database packages 128

3.7.3.2 Typical facilities 129

3.7.4 Overview of Two Database Packages 130

3.7.4.1 Introduction 130

3.7.4.2 CARDBOX 130

3.7.4.3 $D B A S E ~ \| \quad 130$

$3.8 \quad$ COMMUNICATIONS AND 131

$\begin{array}{lll}3.8 .1 & 131\end{array}$

3.8.2 Communications 131

3.8.2.1 Signals and codes 131

3.8.2.2 Bits and bauds 132

3.8.2.3 Packets 133

3.8.3 Networks 133

3.8.3.1 Introduction 133

3.8.3.2 Local area networks 133

3.8.3.3 Wide area networks 135

3.8.4 Taking Advantage of Networks 135

3.8.4.1 Introduction 135

3.8.4.2 Development possibilities 135

3.8.5 Summary 135

\section{EFFECTIVE USE OF YOUR COMPUTER}

4.1

4.1.1

4.1.2

4.1 .3

4.1.4

4.2

4.2.1

4.2 .2

4.2.3

4.3

4.4

4.4.1

4.4 .2

4.4.3

4.4.3.1

4.4.3.2

4.4.3.3

4.4.4

4.4.4.1

4.4.4.2

4.4.4.3

4.4 .5

4.4.5.1

4.4.5.2

4.4.5.3

4.4.5.4

4.4.6

4.4.6.1

4.4.6.2

5

5.1

5.1.1

5.1 .2

5.1 .3

5.1.3.1

5.1.3.2

5.1 .4

5.1.4.1

5.1 .5

5.1.6

5.1.6.1

5.1.6.2

5.1 .7

5.2

5.2 .1

5.2 .2

5.2 .3

5.2 .4

5.2.4.1

5.2 .5

5.2.6

5.3

5.3.1

5.3.2

5.3.3

5.3.4

5.3.5

5.3.6

The Personal Context

The Group Context

Union Considerations

138

ERGONOMIC CONSIDERATIONS 138

Introduction

138
138

Health Aspects

138

The Workstation and its Environment 139

ENVIRONMENTAL CONSIDERATIONS 140

\section{SECURITY}

Introduction

140

Backup

Integrity

140

141

141

Introduction

141

What can happen? 142

Preserving integrity $\quad 142$

Access

Introduction

143

143

Physical access

Logical access

143

144

Integration into the Office 144

Introduction

144

Responsibility and authorisation $\quad 144$

Schedules and procedures
5.4

5.4 .1

5.4 .2

5.4 .3

5.4 .4

5.4 .5

5.5

5.5.1

5.5 .2

5.5.2.1

5.5.2.2

5.5.2.3

5.5.2.4

5.5.2.5

5.5 .3

5.5.3.1

5.5.3.2

5.5.3.3

5.5.3.4

5.5.3.5

5.5 .4
Documentation and records

144

Staying in Touch

Introduction

Information, advice, education

145

145

145

\section{CURRENT TRENDS IN MICROCOMPUTING}

\section{MACINTOSH: THE MACHINE AND ITS147} OPERATING ENVIRONMENT

\section{Background to the introduction of the 147}

Macintosh

Integrating the User Interface into the 147

Operating System

Macintosh Technology Overview 148

Macintosh's User Interface 148

Macintosh's Mouse 148

Software Integration In The Macintosh149

Macintosh Software Support $\quad 149$

Macintosh's Competition $\quad 149$

Using Macintosh 149

Macwrite 149

Macpaint 150

Conclusion - Macintosh as a product 151

THE Grid PORTABLE COMPUTER 151

Portable Market Segmentation $\quad 151$

Grid's Target Market $\quad 151$

Product Components 152

Grid User Interface 152

Common Commands and Data 153

Communications 153

The Competition 155

ADVANCES IN INTEGRATED 156

SPREADSHEETS

Introduction 156

Spreadsheet $\quad 156$

Graphics 157

Database $\quad 157$

Programming 158

$\begin{array}{ll}\text { Conclusions } & 158\end{array}$

INTERACTIVE VIDEODISK $\quad 158$

The Videodisk 158

Videodisk Control $\quad 159$

Video Disk Player Controlled by 159

Microcomputer

Interactive Videodisk Applications $\quad 160$

Applications with Other Technologies 160

OPERATING SYSTEMS

160

Introduction 160

The UNIX Operating System $\quad 161$

Introduction 161

Technical description of UNIX 161

Systems facilities 163

Hardware requirements $\quad 163$

Commercial suppliers 163

The MS-DOS Operating System 163

Introduction 163

Technical description of MS-DOS 164

System facilities $\quad 164$

Hardware requirements $\quad 165$

Commercial suppliers $\quad 165$

The MP/M Operating System 165 


\begin{tabular}{|c|c|}
\hline $\begin{array}{l}5.5 .4 .1 \\
5.5 .4 .2\end{array}$ & $\begin{array}{l}\text { Introduction } \\
\text { Technical description of Concurrent }\end{array}$ \\
\hline $\begin{array}{l}5.5 .4 .3 \\
5.5 .5 \\
5.5 .5 .1 \\
5.5 .5 .2\end{array}$ & $\begin{array}{l}\text { System Facilities } \\
\text { Conclusions } \\
\text { Hardware Requirements } \\
\text { Commercial Suppliers }\end{array}$ \\
\hline & $\begin{array}{l}\text { PERSONAL COMPUTER } \\
\text { NETWORKING }\end{array}$ \\
\hline $\begin{array}{l}\text { 5.6.1 } \\
5.6 .2 \\
5.6 .2 .1 \\
5.6 .2 .2 \\
5.6 .2 .3 \\
5.6 .3 \\
5.6 .3 .1 \\
5.6 .3 .2 \\
5.6 .3 .3 \\
5.6 .4 \\
5.6 .3 .5 \\
5.6 .3 .6 \\
5.6 .3 .7\end{array}$ & $\begin{array}{l}\text { Introduction } \\
\text { Benefits from Local Area Networks } \\
\text { Sharing } \\
\text { Operations } \\
\text { Conclusions } \\
\text { Particular Networks } \\
\text { PC Net } \\
\text { Omninet } \\
\text { Plan } 4000 \text { and Plan } 2000 \\
\text { Sharenet X and Sharenet S } \\
\text { Elan } \\
\text { EtherSeries } \\
\text { Multilink }\end{array}$ \\
\hline
\end{tabular}

\section{6}

6.1

6.1 .1

6.1.2

6.1 .3

6.1.4

6.1.4.1

6.1.4.2

6.1.4.3 Group 3: Standard operating environment

6.1.4.4 Group 4: Modified applications environments

6.1.5 Conclusion

6.2 GROUP 1 - FAMILIES OF APPLICATIONS

6.2.1 Perfect Software

6.2.1.1

6.2.1.2

6.2.1.3

6.2.1.4

6.2.1.5

6.2 .3

6.2.3.1

6.2.3.2

6.2.3.3

6.2.3.4

6.2.3.5

6.3

6.3.1

6.3.1.1

6.3.1.2

6.3.1.3

6.3.1.4

6.3.1.5

6.3.2

\section{Perfect software overview}

Applications available

Ease of use

Conclusions

MicroPro Software

Micropro overview

Applications covered

Integration

Ease of use

Conclusion

GROUP 2: MULTIPLE APPLICATION PACKAGES

Context MBA

Overview

Applications covered

Integration

Ease of use

Conclusion

Lotus 1-2-3
Integration
165

165

166

166

167

167

167

167

167

167

168

168

169

169

171

171

172

173

173

174

6.3.2.1 Overview

6.3.2.2 Applications covered
6.3.2.3 Integration

6.3.2.3

6.3.2.4

6.3.2.5

6.3.3

6.3.3.1

6.3.3.2

6.3.3.3

6.3.3.4

6.3.3.5

6.3.3.6

6.3.4

6.3.4.1

6.3.4.2

6.3.4.3

6.3.4.4

6.3.4.5

6.3.5

6.3.5.1

6.3.5.2

6.3.5.3

6.3.5.4

6.3.5.5

6.3.5.6

177

177

177

178

180

6.3.6

6.3.6.1

6.3.6.2

6.3.6.3

6.3.6.4

6.3.6.5

6.3.7

180

180

180

181

181

6.3.7.1

6.3.7.2

6.3.7.3

6.3.7.4

6.3.7.5

6.4

6.4 .1

6.4.1.1

6.4.1.2

182

182

182

182

182

183

183

183

183

183

184

184

184

185

185

186

186

186

186

186

Ease of use

Conclusions

Lotus Symphony

requirements

Integration

Ease of use

Conclusion

Open Access

Overview

Applications covered

Integration

Ease of use

Conclusions

Decision Manager requirements

Overview

Applications covered

Integration

Ease of use

Conclusions

Overview

Applications covered

Integration

Ease of use

Conclusions

Apple's Appleworks

Overview

Applications covered

Integration

Ease of use

Conclusions

Environments

Concept VP

Integration

Ease of use

6.4.1.4

6.4.1.5

6.4 .2

6.4.2.1

6.4.2.2

6.4.2.3

6.4.2.4

6.4.2.5

6.4.2.6

6.4 .3

6.4.3.1

6.4.3.2

6.4.3.3

6.4.3.4

6.4.3.5

6.4 .4

Conclusion

Desq

Overview

How it works

Applications available

Integration

Ease of use

Conclusions

Window master

Overview

Applications

Integration

Ease of use

Conclusions

In View

6.4.4.1 Overview

6.4.4.2 Applications available

6.4.4.3

6.4.4.4

6.4.4.5

Conclusion
Operating System and hardware

Symphony and 1-2-3 187

Symphony Overview 187

Operating System and hardware

Ashton Tate's Framework

Group 3: Standard Applications

193

193

193

Applications available $\quad 193$

Ease of use 


\begin{tabular}{|c|c|c|c|c|c|}
\hline 6.5 & $\begin{array}{l}\text { GROUP 4: MODIFIED OPERATING } \\
\text { ENVIRONMENTS }\end{array}$ & 196 & $\begin{array}{l}7.6 \\
7.6 .1\end{array}$ & $\begin{array}{l}\text { PORTABLE SURVEY } \\
\text { What to Look for in a Portable }\end{array}$ & $\begin{array}{l}312 \\
312\end{array}$ \\
\hline $\begin{array}{l}6.5 .1 \\
6.5 .1 .1 \\
6.5 .1 .2\end{array}$ & $\begin{array}{l}\text { Windows } \\
\text { Overview } \\
\text { How it works }\end{array}$ & $\begin{array}{l}197 \\
197 \\
197\end{array}$ & 8 & PERIPHERAL SURVEY & \\
\hline $\begin{array}{l}6.5 .1 .3 \\
6.5 .1 .4\end{array}$ & $\begin{array}{l}\text { Applications available } \\
\text { Integration }\end{array}$ & $\begin{array}{l}198 \\
198\end{array}$ & $\begin{array}{l}8.1 \\
8.1 .1\end{array}$ & $\begin{array}{l}\text { GUIDE TO PRINTERS } \\
\text { The Market for Printers }\end{array}$ & $\begin{array}{l}315 \\
315\end{array}$ \\
\hline $\begin{array}{l}6.5 .1 .5 \\
6.5 .1 .6\end{array}$ & $\begin{array}{l}\text { Ease of use } \\
\text { Conclusion }\end{array}$ & $\begin{array}{l}198 \\
198\end{array}$ & $\begin{array}{l}8.1 .2 \\
8.1 .2 .1\end{array}$ & $\begin{array}{l}\text { Points to Watch } \\
\text { Forms handling }\end{array}$ & $\begin{array}{l}315 \\
315\end{array}$ \\
\hline $\begin{array}{l}6.5 .2 \\
6.5 .2 .1\end{array}$ & $\begin{array}{l}\text { VisiOn } \\
\text { Overview }\end{array}$ & $\begin{array}{l}199 \\
199\end{array}$ & $\begin{array}{l}8.1 .2 .2 \\
8.1 .2 .3\end{array}$ & $\begin{array}{l}\text { Noise } \\
\text { Compatibility }\end{array}$ & $\begin{array}{l}315 \\
315\end{array}$ \\
\hline $\begin{array}{l}6.5 .2 .2 \\
6.5 .2 .3\end{array}$ & $\begin{array}{l}\text { Applications manager } \\
\text { Applications available }\end{array}$ & $\begin{array}{l}199 \\
199\end{array}$ & $\begin{array}{l}8.1 .3 \\
8.1 .4\end{array}$ & $\begin{array}{l}\text { How to Buy a Printer } \\
\text { Printer Survey Guide }\end{array}$ & $\begin{array}{l}315 \\
316\end{array}$ \\
\hline $\begin{array}{l}6.5 .2 .4 \\
6.5 .2 .5 \\
6.5 .2 .6\end{array}$ & $\begin{array}{l}\text { Integration } \\
\text { Ease of use } \\
\text { Conclusion }\end{array}$ & $\begin{array}{l}199 \\
199 \\
199\end{array}$ & $\begin{array}{l}8.1 .4 .1 \\
8.1 .4 .2 \\
8.1 .4 .3\end{array}$ & $\begin{array}{l}\text { Introduction } \\
\text { Print features } \\
\text { Font }\end{array}$ & $\begin{array}{l}316 \\
316 \\
316\end{array}$ \\
\hline 6.5 .3 & Lisa & 200 & 8.1.4.4 & Paper handling & 316 \\
\hline $\begin{array}{l}6.5 .3 .1 \\
6.5 .3 .2\end{array}$ & $\begin{array}{l}\text { Overview } \\
\text { Applications covered }\end{array}$ & $\begin{array}{l}200 \\
200\end{array}$ & $\begin{array}{l}8.1 .4 .5 \\
8.1 .4 .6\end{array}$ & $\begin{array}{l}\text { Performance } \\
\text { Interface }\end{array}$ & $\begin{array}{l}316 \\
316\end{array}$ \\
\hline $\begin{array}{l}6.5 .3 .3 \\
6.5 .3 .4\end{array}$ & $\begin{array}{l}\text { Introduction } \\
\text { Ease of use }\end{array}$ & $\begin{array}{l}201 \\
201\end{array}$ & 8.1 .5 & PRINTER SURVEY & 317 \\
\hline 6.5.3.5 & Conclusions & 201 & $\begin{array}{l}8.2 \\
8.2 .1\end{array}$ & $\begin{array}{l}\text { GUIDE TO MONITORS } \\
\text { The Market for Monitors }\end{array}$ & $\begin{array}{l}351 \\
351\end{array}$ \\
\hline 6.6 & BUILDING A SOFTWARE LIBRARY & 201 & 8.2 .2 & Extended Displays & 351 \\
\hline 6.6 .1 & Applications packages & 202 & 8.2 .3 & Points to Watch & 352 \\
\hline $\begin{array}{l}6.6 .2 \\
6.6 .2 .1\end{array}$ & $\begin{array}{l}\text { Financial planning } \\
\text { VisiCalc-VisiCorn }\end{array}$ & 202 & 8.2 .4 & How to Test a Monitor & $\begin{array}{l}352 \\
352\end{array}$ \\
\hline 6.6 .2 .2 & SuperCalc-Sorcim & 202 & $\begin{array}{l}8.2 .4 .1 \\
8.2 .4 .2\end{array}$ & $\begin{array}{l}\text { Bandwidth tests } \\
\text { Power Supply tests }\end{array}$ & 352 \\
\hline $\begin{array}{l}6.6 .2 .3 \\
6.6 .2 .4\end{array}$ & PeachCalc-Peachtree Software & 203 & 8.2.4.3 & Other tests & 352 \\
\hline $\begin{array}{l}6.6 .2 .4 \\
6.6 .2 .5\end{array}$ & $\begin{array}{l}\text { CalcStar - MicroPro } \\
\text { Perfect Calc - perfect software }\end{array}$ & $\begin{array}{l}203 \\
203\end{array}$ & $\begin{array}{l}8.2 .5 \\
8.2 .5 .1\end{array}$ & $\begin{array}{l}\text { A Guide to the Survey } \\
\text { Commercial Information }\end{array}$ & $\begin{array}{l}353 \\
353\end{array}$ \\
\hline $\begin{array}{l}6.6 .2 .6 \\
6.6 .2 .7\end{array}$ & $\begin{array}{l}\text { Multiplan - Microsoft } \\
\text { PlannerCalc - Comshare }\end{array}$ & $\begin{array}{l}203 \\
203\end{array}$ & $\begin{array}{l}8.2 .5 .2 \\
8.2 .5 .3\end{array}$ & $\begin{array}{l}\text { Display } \\
\text { Input }\end{array}$ & $\begin{array}{l}353 \\
353\end{array}$ \\
\hline 6.6 .3 & Databases & 203 & 8.2.5.4 & Bandwidth & 353 \\
\hline $\begin{array}{l}6.6 .3 .1 \\
6.6 .3 .2\end{array}$ & $\begin{array}{l}\text { dBase II - Ashton Tate } \\
\text { Delta - Compsoft }\end{array}$ & $\begin{array}{l}203 \\
203\end{array}$ & 8.2.6 & Monitor Survey & 352 \\
\hline $\begin{array}{l}6.6 .3 .3 \\
6.6 .3 .4\end{array}$ & $\begin{array}{l}\text { Rescue - Qudos } \\
\text { Retrieve II - Derwent Data Systems }\end{array}$ & $\begin{array}{l}203 \\
203\end{array}$ & 8.3 & $\begin{array}{l}\text { GUIDE TO DISK DRIVES AND DISK } \\
\text { BACK UP }\end{array}$ & 360 \\
\hline 6.6.3.5 & Tomorrow's Office - Sosoft & 203 & 8.3.1 & The Market for Low-Cost Drives & 360 \\
\hline $\begin{array}{l}6.6 .3 .6 \\
6.6 .3 .7\end{array}$ & $\begin{array}{l}\text { Condor - MOM } \\
\text { Cardbox - Caxton/Business } \\
\text { Simulations }\end{array}$ & $\begin{array}{l}203 \\
204\end{array}$ & $\begin{array}{l}8.3 .2 \\
8.3 .2 .1 \\
8.3 .2\end{array}$ & $\begin{array}{l}\text { Winchester Drives } \\
\text { Winchester Options } \\
\text { Hardware Considerations }\end{array}$ & $\begin{array}{l}360 \\
361 \\
361\end{array}$ \\
\hline 6.6 .4 & Word Processing & 204 & 8.3.2.3 & Software Considerations & 364 \\
\hline 6.6.4.1 & WordStar - MicroPro & 204 & 8.3.3 & Tape Back Up & 364 \\
\hline $\begin{array}{l}6.6 .4 .2 \\
6.6 .4 .3\end{array}$ & Easywriter II - IBM & 204 & 8.3.3.1 & The Tape Back Up Market & 364 \\
\hline $\begin{array}{l}6.6 .4 .3 \\
6.6 .4 .4\end{array}$ & Multimate - CBIS & 204 & 8.3.3.2 & Hardware Issues & 364 \\
\hline $\begin{array}{l}0.0 .4 .4 \\
6.6 .4 .5\end{array}$ & $\begin{array}{l}\text { Spellbinder } \\
\text { Perfect Writer - Perfect Software }\end{array}$ & $\begin{array}{l}204 \\
204\end{array}$ & $\begin{array}{l}\text { 8.3.3.3 } \\
8.3 .4\end{array}$ & $\begin{array}{l}\text { Software Issues } \\
\text { A Guide to the Survev }\end{array}$ & $\begin{array}{l}364 \\
365\end{array}$ \\
\hline $\begin{array}{l}6.6 .4 .6 \\
6.6 .4 .7\end{array}$ & Volkswriter - $\mathrm{CACl}$ & 204 & 8.3.5 & Disk Survey & 365 \\
\hline & & & 8.4 & BUYERS' GUIDE TO VIDEO & 369 \\
\hline 6.7 & CONCLUSIONS & 204 & & & \\
\hline & & & $\begin{array}{l}8.4 .1 \\
8.4 .2 \\
8.43\end{array}$ & $\begin{array}{l}\text { The Market for Video Terminals } \\
\text { Points to Watch }\end{array}$ & $\begin{array}{l}369 \\
369 \\
369\end{array}$ \\
\hline 7 & MICROCOMPUTER SURVEY & & 8.4 .4 & A Guide to the Survey & 370 \\
\hline 7.1 & MICROCOMPUTER SURVEY & 207 & & & $3 / 0$ \\
\hline 7.2 & MICROCOMPUTER SYSTEMS & 207 & \multirow{2}{*}{\multicolumn{2}{|c|}{$\begin{array}{l}\text { APPENDIX A CHECKLIST FOR WORD } \\
\text { PROCESSING }\end{array}$}} & 381 \\
\hline \multirow{2}{*}{7.3} & INDFX & 207 & & & \\
\hline & MANUFACTURERS & & \multirow{4}{*}{$\begin{array}{l}\text { A.1 } \\
\text { A.2 } \\
\text { A.3 } \\
\text { A.4 } \\
\text { A.5 }\end{array}$} & \multirow{4}{*}{$\begin{array}{l}\text { Objectives } \\
\text { Standard facilities } \\
\text { Ease of operation } \\
\text { Overall performance } \\
\text { Additional features }\end{array}$} & \\
\hline 7.4 & TABLE OF POPULAR PACKAGES & 209 & & & $\begin{array}{l}381 \\
381\end{array}$ \\
\hline & & & & & \\
\hline 7.5 & THE SURVEY & 212 & & & 381 \\
\hline
\end{tabular}


APPENDIX B CHECKLIST FOR MICROCOMPUTER382 CONSUMABLES

B.1 The market for consumables 382

B.2 How to buy consumables 382

B.3 Consumables checklist 382

B.4 Mail order companies 382

APPENDIX C SOURCES OF ADVICE 383

C.1 Organisations

383

C. 2

Nationwide help for small businesses 383

C.3

Publications

\section{APPENDIX D CONTRACTS}

385

D. 1

Introduction

385

D.2 Contracts Provisions

385

D.3 Conclusion

APPENDIX E VAT AND THE MICROCOMPUTER - A CUSTOMS AND EXCISE 386 VIEWPOINT

$\begin{array}{ll}\text { E.1 } & \text { Background } \\ \text { E.2 } & \text { Introduction } \\ \text { E.3 } & \text { Assistance from HM Customs and } \\ & \text { Excise } \\ \text { E.4 } & \text { Value Added Tax }\end{array}$

E.4.1

General

E.4.2 VAT accounts 386

E.4.3 Early consultation 386

E.4.4 Audit trail 386

E.4.5 Retention of records 387

E.4.6 VAT rates 387

E.4.7 Calculation of tax 387

E.4.8 Exports 387

$\begin{array}{lll}\text { E.4.9 Retailers } & 387\end{array}$

E.4.10 Self billing 387

E.4.11 Credits 387

E.4.12 Purchase systems 387

E.4.13 Data interchange 387

APPENDIX F FINANCIAL SERVICES 388

F.1 Acquisition implications 388

F.2 Leasing organisations 388

APPENDIX G INSURANCE SERVICES 389

G.1 What can a policy cover? 389

G.2 Insurance organisations 389

APPENDIX H MAINTENANCE SERVICES 390

H.1 Third party maintenance 390

H.2 Maintenance organisations 390

APPENDIX I MICROCOMPUTER PRICES 392

APPENDIX J GLOSSARY 396 


\section{AXIS for total support}

* Computers

* Peripherals

* Software

* Consumables

* Consultancy

AXIS

provide BUSINESS SYSTEMS from \$900, comprising:

* Disk-based micro (400/800K)

* $80 \mathrm{cps}$ dot matrix printer
* Keyboard

* Monitor

PLUS Word Processing, Spreadsheet and Utility software PLUS Full "hot-line" support service

AXIS

specialise in VERTICAL MARKET SOFTWARE:

* Accountancy

* Insurance

* Fleet Management

* Printing \& Publishing
* Medical

* Construction

* Retailing

* Agriculture

YS for PLOTTERS, DOT MATRIX, DAISYWHEEL and LINE PRINTERS from $\mathbf{\$ 2 2 0}$

AXIS

PERSONAL COMPUTER PRODUCTS
Eden House

32 Well Road

Maidstone

Kent ME14 1XL
Telepphone:

Maidstone (0622) 58688

Telex:

965633G 


\section{INTRODUCTION}

The Microcomputer Users Handbook has been written for all business people and professionals who are current or potential users of microcomputer systems. This practical guide will help the reader to select or upgrade the right microcomputer as well as explain how to successfully operate the chosen system.

This Handbook will aid a wide range of business people: self-employed people running small businesses, accountants in larger companies, managers of company divisions, DP managers, university lecturers, architects, doctors, and many more. It will, of course, be immensely useful to microcomputer and peripheral computer manufacturers and dealers. Indeed, it is invaluable to all those involved in the computer business who require a comprehensive source of international information.

Many books have attempted to cover this topic but none have described as many makes of microcomputers and peripherals in such detail. The area of microcomputer technology is so rapidly changing that it is understandable why this has not been properly attempted before now. The authors realise that although machines and models will change, the information contained in this Handbook will still prove valuable. To help overcome the problem of providing up-to-date information, this Handbook will be revised and published every year. The authors welcome readers' and manufacturers' comments and suggestions for amendments and additions for the next edition. These should be sent to:

Dennis Longley and Michael Shain

The Microcomputer Users Handbook

Macmillan Reference Books

4 Little Essex Street

London WC2R 3LF

\section{HOW TO USE THE HANDBOOK}

The Handbook is divided into two parts:

The first part comprising Chapters $1-6$ assesses and explains the user's needs in choosing the appropriate microcomputer system.

The second part including Chapters $7-8$ is an indepth review of over 160 business microcomputers. It also describes in similar detail the peripherals:
VDU's, disk drives, printers and monitors currently available.

The paragraphs below further explain which chapters will be of most use to different readers. As the reader can see from the detailed content pages, the chapters and sections within chapters have been largely designed to be self-contained. This will enable each reader to select the appropriate chapters, sections and sequence of reading for his or her own requirements.

The reader seeking a microcomputer within a specific price range should refer to Appendix I which provides a most comprehensive and practical listing of all the microcomputers according to price range. For each model the following information is provided: operating system(s), hard disk availability and whether multi-user or networking is supported.

The user with no knowledge of microcomputers should first read Chapter 1 and the appropriate subsections in Chapter 2 (see below), to set the scene. The sections in Chapter 3 describe important applications of business microcomputers and assumes a general understanding of the role and function of microcomputers as given in the previous two chapters. The reader who is concerned with the problems of installation, and implementation, of the computer system is directed to Chapter 4 where the technical, ergonomic and administrative problems associated with these phases are comprehensively covered. Chapter 5 provides an insight into particular developments in the microcomputer field and will be of most interest to users who already have some microcomputer experience. Chapter 6 gives an account of recent developments in integrated software and will enable the user to build a software library.

The actual details of equipment and manufacturers in Chapters 7 and 8 are preceded with further explanatory notes which provide hints on the relevance of technical aspects from a users' and purchasers' viewpoint. The recurring theme of this Handbook is that the user is primarily concerned with the operation of the total computer system; it is therefore important that those technical factors are kept in their proper perspective.

The appendices provide details of ancillary services and suppliers, a checklist for word processing applications, advice from $\mathrm{H}$ M Customs and Excise on VAT aspects, advice on contracts, an overview of microcomputers listed by price and a glossary. 


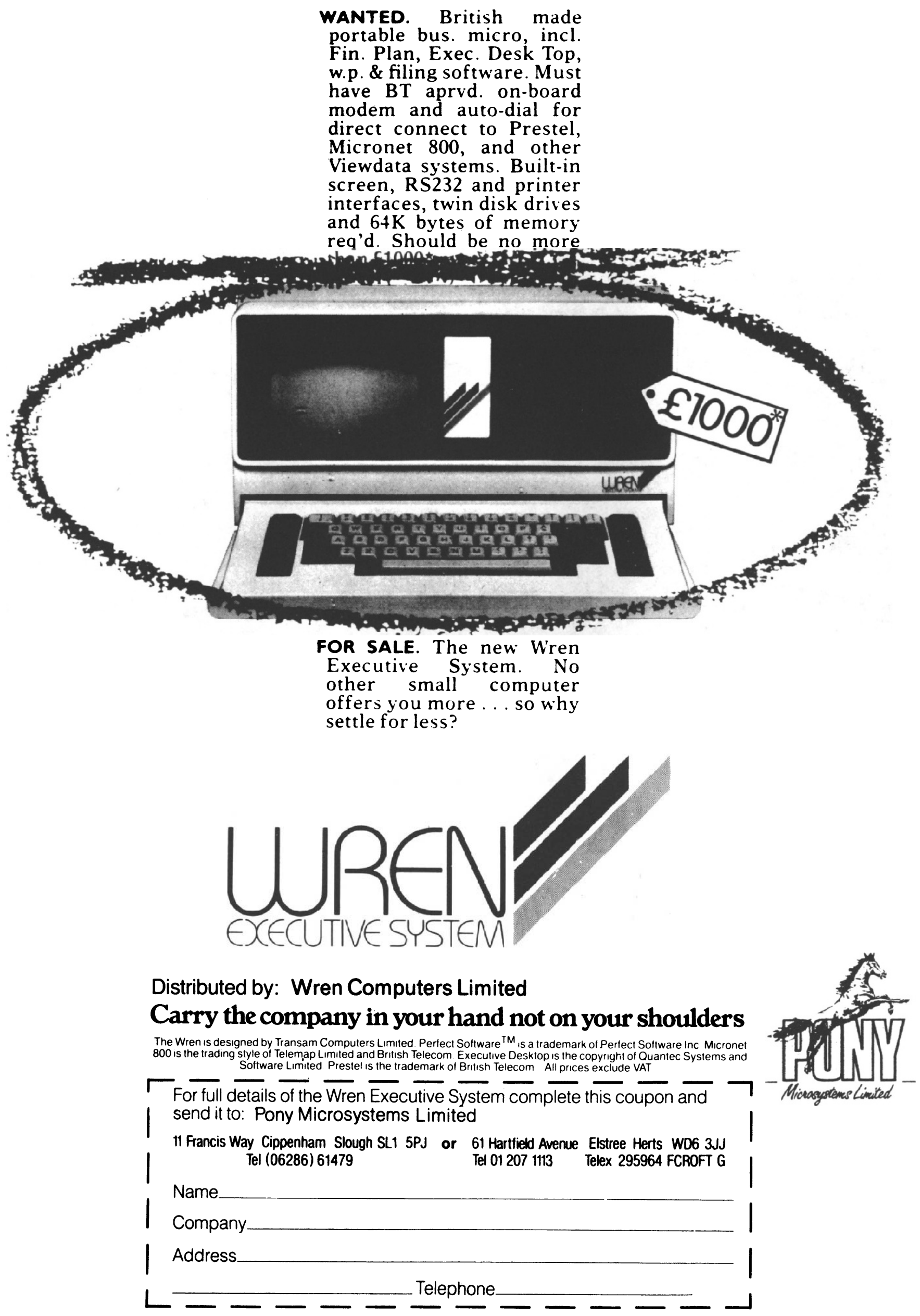




\section{ABOUT THE CHAPTERS}

\section{HOW TO BUY A MICROCUMPUTER}

by $R$ Anderson, Brighton Polytechnic.

The role of the microcomputer in business is analysed and suggestions are made on the approach to be taken in acquiring a microcomputer, together with questions which should be asked at a demonstration. Due attention is given to the planning for growth, and the importance of maintenance and after-sales support is discussed. Supporting material is also contained in the appendices (see below) where specific advice is given on sources of help, maintenance, finance etc.

\section{UNDERSTANDING MICROCOMPUTERS}

by D Longley, Brighton Polytechnic.

This chapter comprises eleven sections dealing with the hardware and software of microcomputers. The Chapter may be read in its entirety as a general introduction to the subject but it is also organised to facilitate selection of topics in isolation. Each section is preceded with a few explanatory paragraphs which attempt to place the material in context and most sections provide both an overview, and a detailed account, of the topics. In appropriate cases the concluding paragraphs indicate the interrelationship of other sections in the chapter.

\section{IMPORTANT APPLICATIONS}

This chapter is mainly concerned with those software packages likely to be of importance to the business user. There is a degree of cross reference between its sections but it has been largely designed so that the reader may select the most relevant application area.

Word Processing by A Warburton, Brighton Polytechnic. This gives a full account of the more important facilities that a word processing package should contain and considers the WORDSTAR package in detail.

Financial Planning by B Elliot, Brighton Polytechnic. The growth of financial modelling on microcomputers is discussed and the more important spreadsheet packages analysed and compared. A full account is presented of VISICALC and its areas of application reviewed.

Scheduling by M Cotterell, Brighton Polytechnic. Scheduling, like Financial Planning, can be used both to formulate a business plan and to monitor subsequent progress. This application covers both critical path analysis, work-in-progress and production control. The asking of 'what if?' questions enables the user to interact with the microcomputer.

Sales Ledger by D Longley, Brighton Polytechnic. Sales Ledger packages have a widespread appeal in the business microcomputer field since they can both reduce the manual effort of a common bookkeeping task and improve the information available on sales and creditors. The main features of such packages are described in this section.

Integraded Accounting Packages by $M$ Shain, NCC. The benefit of a fully integrated accounting system is that a single keyboard entry will automatically update all the relevant ledgers. Budgetary information, variance analysis and trial balances can be produced on a demand basis.

Incomplete Records by B Elliot, Brighton Polytechnic. Incomplete Records is a technique used by accountants in practice to produce year end tax returns for the Revenue. It is a good example of the application of microcomputing in a professional area.

Database Packages by S Fall, Brighton Polytechnic. A database system provides a well defined structure for information, stored on a computer, which both facilitates processing by a variety of application programs and supports a fast response for ad hoc enquiries. This important topic is discussed in detail and two microcomputer database management packages are described.

Communications and Networking by A Warburton, Brighton Polytechnic. The various methods by which microcomputers can be linked to share common resources such as disk and printers is reviewed. An account is also given on several proprietory systems.

\section{EFFECTIVE USE OF YOUR COMPUTER}

by $A$ Warburton, Brighton Polytechnic.

The microcomputer cannot be considered in isolation of the office environment where it is to operate. The correct siting and positioning of the microcomputer, lighting and desktop layout all need to be considered. This chapter reviews the ergonomic and human factor elements involved in the successful integration of the microcomputer into the day-to-day operation of a business. Security procedures, particularly for auditing and file backup purposes, are fully reviewed and codes of practice suggested.

\section{CURRENT TRENDS IN MICROCOMPUTING}

This chapter reviews recent developments in the design of hardware, software and communication interfaces for the modern microcomputer. These sections will be useful to the reader in establishing the relationship between the microcomputer and the more traditional elements of computing.

MACINTOSH by I Scales, Greenleaf Publishing. The first time user can operate the Macintosh in under 20 minutes. It has a remarkable user interface, but not without some limitations.

GRiD Portable Computer by $\mathrm{H}$ Mooney, GRiD Inc. The GRiD is a lightweight (10 lbs), powerful 16 
bit machine with bubble memory, plasma display and integral modem. It is representative of the new generation of portables which now account for one third of all microcomputer sales.

Advances in Integrated Spreadsheets by D Longley, Brighton Polytechnic. Packages such as Lotus 1-2-3 and Symphony are powerful productivity tools. In effect, they are programming languages and this section explains why they need to be handled with caution.

Interactive Video Disk by C Jackson, Brighton Polytechnic. Controllers now available for the video disk machine enable it to be used as an interactive peripheral on a microcomputer. The video disk, with its high definition graphics and large storage capacity, has immediate applications in computer based training.

Operating Systems by A King, Microsoft and $M$ Shain, NCC. UNIX, MS-DOS and Concurrent DOS are reviewed and their respective merits compared. Networking and Windowing requirements will influence the choice of an operating system.

Personal Computer Networking by C Oswald, Reuters Ltd. A local area network is required if two or more users need to share the same files. The criteria for network selection are reviewed and leading networking products are compared.

\section{INTEGRATED SOFTWARE}

by M Shain, NCC, I Scale and G Wheelwright, Greenleaf Publications, C Barker, Which Computer.

This chapter has two objectives: to examine the rising trend in integrated software and act as a purchasing guide to that software. The principle characteristic of integrated software is the ability to transfer data from one application to another, e.g. from communications to spreadsheet to word processing. Most integrated software packages include windowing, help facilities, pointing devices and command simplicity.

Integrated software can be classified into four main families and the packages available within each category are reviewed. All will feature database, word processing, spreadsheet, graphics and communications facilities. The four classes of integrated software are:

(i) Families of Applications, e.g. Perfect series from Perfect Software, Star series from MicroPro.

(ii) Multiple Application Packages, e.g. Lotus 1-2-3 and Symphony.

(iii) Standard Operating Environments, e.g. Concept VP from Scienta, Desq from Quarterdeck.

(iv) Modified Applications Environments, e.g. Apple's Lisa and Macintosh, VisiON from VisiCorp and Microsoft's Windows.

\section{COMPUTER SURVEY}

by S Fineberg and M Shain, NCC

This survey contains details of over 160 microcomputers which can be employed in a business environ- ment. They range from the inexpensive home computers which may be adapted to business applications through the purpose designed Personal Computer to machines capable of hosting networks with power and facilities close to the minicomputer range.

The ultimate selection of a particular microcomputer system demands an interactive approach and the reader will not be able to select the most appropriate hardware by a perusal of this chapter alone. A discussion with a reputable dealer, together with demonstrations, will focus attention on one or two appropriate systems. A study of Appendix I will then provide details of other microcomputers in a similar price range. Chapter 6 will enable the reader to extend consideration to other manufacturers' models which may be equally suitable, probably leading to further discussions and demonstrations. Thus at the point of final decision the purchaser can be reasonably assured that a sensible range of alternatives has been evaluated.

The machines are described in a common format and the abbreviated nature of this survey necessitates the use of technical terms. However the glossary and Chapter 2 will provide some clarification of these technical aspects within the context of the Handbook.

The information in this chapter has been gleaned from a variety of sources, including manufacturers' literature, and every reasonable attempt has been made to confirm the accuracy of its contents. However it must be emphasised that this data is subject to rapid market and technological developments and details must be checked with the appropriate dealer before any final decision on system acquisition is made.

\section{PERIPHERAL SURVEY}

by M Shain, NCC.

The peripherals represent both the interface between the user and the processor and also the means of storing data and software between computer runs. The first time purchaser is advised, in Chapter 1, to acquire a total system geared to his business requirements and warned of the dangers inherent in the isolated purchase of the individual components. Nevertheless the user must pay careful attention to the performance of peripherals both on first purchase and on subsequent expansion of the system. The user will therefore be very concerned with the ergonomics of the input output devices and the reliability and capacity of backing store. The sections in this chapter provide a discussion on the relevant technical factors, from a user and purchaser viewpoint, of four types of peripheral-printers, monitors, disk storage and terminals plus information on a range of manufacturers' models.

\section{APPENDICES}

There are many aspects of microcomputer purchase, installation and maintenance that are of crucial importance to the user but are, all too often, unavailable to the newcomer. These appendices attempt to remedy this deficiency; they provide useful details of advice and ancillary services in 
addition to a glossary and an overview of the microcomputer market.

Appendix A: Checklist for Word Processing.

Appendix B: Checklist for Microcomputer Consumables.

Appendix C: Sources of Advice.

Appendix D: Checklist for Computer Contracts. Appendix E: VAT-Customs and Excise Requirements.

Appendix F: Financial Services.

Appendix G: Insurance Services.

Appendix H: Maintenance Services.

Appendix 1: Microcomputer Prices.

Appendix J: Glossary of Terms.

\section{ACKNOWLEDGEMENTS} The editors would like to thank Joy Figgins, for her help in project coordination and research, Sylvia Tinkler for her assistance in the compilation of the printer survey, and Rosemary Foster, Lysa Schwartz and John Hodgson of Macmillan for turning the manuscript into the finished book. The editors would also like to thank Mr D Teacher for his article on Computer Contracts, Appendix D. 
a range of books that incorporate the very latest technology, presented in a highly readable style - books that show you how to make the most effective use of your money and your micro.

UNDERSTANDING
MICROCOMPUIERS

Dennis Longley and Michael Shain

The book that takes the terror out of meeting

the micro. A basic guide for the would-be user.

Step-by-step explanation of

* the components of a microcomputer system

* the organisation of business data

* hardware and peripherals

* software - including programming,

operating systems, languages, applications.

160pp $0333375734 \quad £ 5.95$

\section{EXPANDING AND} NETWORKING

\section{MICROCOMPUTERS}

Dennis Longley and Michael Shain

You can upgrade your machine by adding expansion boards. This is the only book that describes hundreds of boards for both the IBM PC and the Apple II microcomputer. In addition it covers:

\section{* Apple 'lookalikes'}

* how to convert Apple II files to the IBM PC

* microcomputer buses

* networking

* protocols for emulation

320pp

0333380061

$£ 24.95$

\section{THE UITIMATE}

SOFIWARE SELECIOR

Compiled by the Federation of Microsystem and Industry Centres supported by the Department of Trade

A detailed guide to over 1000 packages available in the UK:

* all packages listed have full UK service backup

* areas covered include: Database,

Accounting, Inventory Control, Payroll, OR Systems etc., plus packages for specific trades and professions, e.g. solicitors, retail

* shows AT A GLANCE which packages best suit the buyer's requirements, hardware ... and budget.

\section{0pp $\quad 0333375564 \quad £ 9.95$ \\ DICIIONARY OF INFORMATION TECHNOLOGY 2nd Edition}

This first, highly acclaimed, book from experts Longley and Shain, has been substantially revised to include definitions of even the very latest terms and concepts.

Key topics treated in depth:

* Videotex * Information Technology * Programming * Computer Networks * Word Processing * Microcomputers * Typesetting * Educational Technology 448 pp illustrated $0333372603 \quad £ 25.00$ Hardcover 0333372611 E8.95 Paperback

TO ORDER: All these books are available from your local Bookseller. In case of difficulty please write to: The Product Manager, Macmillan Press Ltd., Houndmills, Basingstoke, Hants RG21 2 XS or telephone (0256) 29242. 